\title{
Re-Design of Schoolyard for Effective Development of Child From a Universal Design Perspective
}

\author{
Etkili Çocuk Gelişimi İçin Evrensel Tasarım Perspektifinden \\ Okul Bahçesi Tasarımı
}

Selda AL ŞENSOY, ${ }^{\oplus}$ Reyhan MidiLLI SARI ${ }^{2}$

Contrary to common belief; schoolyard, canteen, circulation areas etc. are important learning environments in learning process as much as classrooms. A well-designed inclusive schoolyard can supply cognitive, physical, social/ emotional, sensory and communicational, briefly the developmental needs of children. Therefore, it is important to provide an appropriate sphere for learning in whole school environment. In this context, purpose of the study is to investigate the supportive schoolyard physical conditions that has an important effect on child's learning, creativity, brain and body development/health and social interaction. Also study focuses on the schoolyard usage by all children with different abilities and limitations to help them for using schoolyard safely and socializing with other pupils. In the study, a landscape project is developed for Atatürk School Complex according to pupils' and teachers' wishes and acquired knowledge which will support their learning, creativity, and social interaction with the conscious of universal design and at the end of the study considerations which is about schoolyard were mentioned briefly.

Keywords: child development; learning; schoolyard; universal design.

Öz

Genel inancın tam tersine, okul bahçesi, kantin, sirkülasyon alanları vs. öğrenme sürecinde sınıflar kadarönemli eğitim mekanlarıdır. Dolayısıyla iyi tasarlanmış kapsayıcı okul bahçeleri çocuğun bilişsel, fiziksel, sosyal/duyusal, iletişimsel, kısaca gelişimsel ihtiyaçlarını destekler. Bu nedenle, bütün okul çevresinde öğrenmeye uygun ortamlar oluşturmak çok önemlidir. Bu çalışma ile çocuğun öğrenmesinde, yaratıcılığında, beyin ve vücut gelişimi/sağlığında, sosyal etkileşiminde önemli etkileri olan destekleyici okul bahçelerinin fiziksel koşulları incelenmiştir. Çalışmada ayrıca farklı yetenek ve kısıtlamalardaki bütün çocukların okul bahçesini güvenli biçimde kullanmalarına ve diğer öğrencilerle sosyalleşmelerine yardımcı olacak okul bahçesi tasarımı üzerine yoğunlaşılmıştır. Literatürden elde edilen bilgiler doğrultusunda ve Atatürk Okul Kompleksi öğrenci ve öğretmenlerinin okul bahçeleri ile ilgili istekleri dikkate alınarak evrensel tasarıma uygun, çocuğun öğrenme, yaratıcılık ve sosyal iletişimini destekleyecek okul bahçesi tasarımı geliştirilmiştir. Çalışma sonunda okul bahçeleri ile ilgili dikkat edilmesi gereken hususlara da değinilmiştir.

Anahtar sözcükler: Çocuk gelişimi; öğrenme; okul bahçesi; evrensel tasarım.

'Department of Architecture, Recep Tayyip Erdoğan University Faculty of Architecture, Design and Fine Arts, Rize, Turkey ${ }^{2}$ Department of Architecture, Karadeniz Technical University Faculty of Architecture, , Trabzon, Turkey

Article arrival date: January 02, 2018 - Accepted for publication: April 16, 2019

Correspondence: Selda AL ŞENSOY. e-mail: seldaal@ktu.edu.tr

๑ 2019 Yıldız Teknik Üniversitesi Mimarlık Fakültesi - ๑ 2019 Yıldız Technical University, Faculty of Architecture 


\section{Introduction}

Play is the lens through which children experience their world and the world of others. It is essential for the appropriate cognitive and social development including cognitive skills, language skills, ability to focus, social, and emotional development of children and have important impacts on shaping the character of child. It also has a crucial role in the health, growth, and development of the brain, body, and intellect and also is one of the best ways for supporting interpersonal, physical, emotional, and cognitive development of the child. Many of the fundamental tasks that children must achieve, such as exploring, risk-taking, fine and gross motor development and the absorption of vast amounts of basic knowledge, can be most effectively learned through outdoor play with participation and with users having different abilities and limitations. ${ }^{1}$ So it can be said that outdoor play and natural environments facilitate children's cognitive and social developmental process and they also benefit physical health and motor development. In a similar approach, New Jersey School Outdoor Area Working Group (2007) defends that appropriate outdoor creates increased opportunities for creativity and social interactions. ${ }^{2}$ But, the rapid structuring of land, combined with technological and social changes, have created tremendous shifts in children's everyday lives. Changing everyday places and activities of children affect not only intellectual perception but also the physical, emotional, social and spiritual structure of them. ${ }^{3}$ Kevin Lynch noted, "In childhood, we form deep attachments to the location in which we grew up and carry the image of this place with us for the remainder of our lives." ${ }^{4}$ Unfortunately, children play less freely in neighborhoods because of dangerous urban environments. The outside environments that are designed by ignoring the importance of play in child development are usually poorly designed with expanses of hard surfaced material enclosed by perimeter fencing. So, school grounds where a child spends important amounts of time are probably the first public environment, thus it has an essential role in child life. For vast numbers of our youth, formal school grounds are the only outdoors they experience. ${ }^{5}$ In this context, schoolyard design, construction, and operation become an important subject of the best practices and the latest researches on the effects of well-designed outdoor areas for the cognitive, physical, social, emotional and developmental needs of children. ${ }^{6}$

As with the school building, the use of the schoolyard is dependent upon the condition of the facility and upon the site's programmatic content. Traditionally, schoolyards

\footnotetext{
Johnson et al., $2010.5 \quad 5$ Nabhan and Stephen, 1995.

2 New Jersey School Outdoor 6 Nabhan and Stephen, 1995; New Jersey Area Working Group, 2007. School Outdoor Area Working Group,

3 Johnson, 1998.

4 Lynch, 1995.
}

have been mostly seen as recreational open spaces that may contain ball fields and courts or play structures in Turkey. At worst, they may have become unsafe vacant lots or parking annexes. As well, pupils with different abilities and limitations are overlooked. So, over the past several years, we have seen an emerging effort to tie school grounds to the core mission of the school for teaching, learning and socializing etc. ${ }^{7}$

The design of a space can support or sabotage its intended use. Therefore while designing a space; the designer should consider its purposed use and potential users. According to the research of New Jersey School Outdoor Area Working Group (2007), the positive benefits of play areas can only occur if the environment is designed to take care of all users. Therefore, space has to accommodate all potential users with different needs as far as possible, including those with physical, cognitive, auditory or visual limitations. ${ }^{8}$ In this context, universal design aims to improve the built environment through the design of facilities, products, and spaces which are accessible, functional, attractive, safe and equal to all. Abend (2001) defines the universal design in school as accommodating users with agility, perceptual acuity, and temporary or permanent changes in mobility, in the maximum extent possible. With the increase in both the number and severity of pupils with disabilities, universal design becomes an important design principle for school architecture. ${ }^{9}$ According to Warren (1994), children with disabilities need interventions to promote interaction with others and to reduce social isolation. ${ }^{10}$ The inclusive character of universal design doesn't remove differences but incorporates them into design and also avoids coming into prominence the differences. So, while providing an effective built environment through school design, all pupils' needs, especially those who have special arrangements because of their varied limitations, are installed to the design process in the light of universal design.

An accessible and inclusive space is designed to create varied and interesting play opportunities for children of all abilities. It fosters shared play by providing universal access to fun and appealing areas at the heart of the play space. ${ }^{11}$ So, the key features of an inclusive play environment are person-accessible, activity based, sensory rich, developmentally appropriate and flexible. A play area should promote a variety of types of activities, rather than fill an equipment list. ${ }^{12}$ And also it must be known that if a design works better for people with disabilities, it works better for everyone..$^{13}$ In this context, the study aims to

\footnotetext{
Education Development Center, ${ }^{10}$ Warren, 1994. 2000.

8 New Jersey School Outdoor Area ${ }^{12}$ OWP/P Cannon Design, vs FurniWorking Group, $2007 . \quad$ ture and Bruce Mau Design, 2010.

9 Abend, 2001.
} 
determine the spatial quality and the inclusivity of an existing schoolyard from a universal design standpoint and to improve user participation design. The main purpose of the study is to re-design an effective schoolyard which contributes to the child's development (play activity, education-teaching, and learning). The study was carried out in Atatürk School in Trabzon. Literature review, observations in the existing schoolyard, interviews, and drawings of teachers and pupils were used in the study to improve the physical conditions of the schoolyard. Finally, a new schoolyard project was designed with findings from all these studies.

\section{Schoolyards as Inclusive Learning and Playing Areas}

Schoolyards are perhaps the most important urban open spaces in the crowded, congested and unplanned cities. When located centrally, opened to neighborhood residents, integrated into the educational system, including all potential users whenever possible, schoolyards will be the most effective open spaces for the settlements. Also, schoolyards are different from parks and playgrounds. Their proximity to schools demands a higher degree of interactivity and they offer us the opportunity to combine recreation, creative play, and academic learning.

Schoolyards are one of the best alternative learning environments. Experiential learning theory which is developed by the early twentieth-century educator and philosopher John Dewey and called for making curriculum meaningful through the child's environment and experiences, emphasize on the importance of outdoors in the learning process. ${ }^{14}$ Experiential learning, which takes place in the outdoor environment, has given a new dimension to the education system. According to theory, any subject that can be taught inside a classroom can be taught as well and perhaps better in the outdoors. For example, many schools are experimenting with planting trees, gardens or natural areas. The act of planting and caring for a tree, observing its growth cycles throughout the year, and discussing its duty within the surrounding built or natural ecosystem, is a "learn by doing" activity that can be conducted in most schoolyards.

Many schoolyard projects also lend themselves to community service learning by interacting with the surrounding neighborhood. ${ }^{15}$ Rather than learning about clouds, weather patterns, light and shadow, water, air quality or trees from textbooks alone, pupils can conduct in-depth in investigations through direct observation, data collection, and analysis. Integrating outdoor study into the core curriculum offers pupils direct, hands-on experience and "real world" applications. A school with a garden provides that unique opportunity to activate a child's awareness of the environment in a lasting way. Experiences in the gar-

\footnotetext{
14 Johnson, $2007 . \quad 15$ Johnson, 1998.
}

den provide what no book or video can. When children are immersed in an enriched environment, their brains are awakened and new growth is inspired. ${ }^{16}$ Schoolyard learning activities also lend themselves to a multi-disciplinary approach. A school garden can be an instructional tool for teaching math (measuring \& counting), science (environment), literacy (journal writing), social studies (urban agriculture) and art (scarecrows). And also, in the study of Arbogast and his friends (2009), they determined that schoolyards which are the rich aspect of planting, contribute to the development of a sense of responsibility, cause allocating more time for games and activities and have positive impacts on conceptual development. ${ }^{17}$ In this context; primary spaces and equipment to be planned in schoolyard design are ceremony areas, arranged sports and play areas, outdoor classrooms, art and performance areas, exhibition areas, natural areas, plant growing gardens, social activity areas, parking areas, semi-open areas protecting from rain and sunlight, particular areas for impaired pupils, play elements, drama stage, table tennis, sandboxes and water pools.

Current patterns and scales of urbanization also reduce children's access to nature. Thus, schoolyard should be taken into account in that the need to be connected to the outdoors is much stronger when we are young. For children, time to be in nature offers unique benefits to their cognitive, physical, emotional, and social development. An extensive study by LTL (Learning Through Landscape) of children's perceptions of their school grounds showed that children find symbolic values in natural elements, and these elements inspired creative play. ${ }^{18}$ Another LTL study of 400 schools indicated numerous benefits of well-designed grounds, including "the development of physical skills, the building of confidence through exploration of the environment and the acquisition of social and behavioral skills through learning to participate and share with others." ${ }^{19}$

Another critical issue is that schoolyards have effects on pupils' health. In many schools, there is not a sports hall or enough sports area. In this kind of schools, if not given more appropriate outdoors, pupils have to expend their energies in the hallways or classrooms. Thus, this condition affects negatively pupils' health. Whereas, healthy play supports playgrounds as a free place for children to burn calories as well as built motor skills. According to Özdemir and Çorakçı (2011), pupils, who are active during the breaks, are healthier than their passive friends. Thus, pupils who spend their times in the more accessible and green schoolyards doing much more activities, are healthier. ${ }^{20} \mathrm{~A}$ study which is about the relationship between phys-

\footnotetext{
${ }^{6}$ Menino, 2000.

${ }^{17}$ Arbogast et al., 2009, pp.450-456.

18 Titman, 1994.

${ }^{19}$ Stoneham, 1997, pp. 23-26.

${ }^{20}$ Özdemir and Çorakçı, 2011.
} 
ical characters of school and bad habits of pupils find out that pupils can be affected by the school and its environment's physical features and well design schoolyards can increase the pupils' attendance and decrease bad habits like smoking, alcohol, drug use. ${ }^{21}$

Schoolyards are also the integration areas of the school and the society. Although it is the pupils whom the first comes to mind as users of the schoolyards, the residents of the district who have varied abilities and limitations-no matter they are child or adult- are also the potential users of the school gardens. So from the beginning of the design process, the residents and their requirements should also be considered and the schoolyard should be open during/ after school hours for the inhabitants of the neighborhood.

The real benefits of schoolyards only occur if the environment is designed to benefit all users. A schoolyard or building designed to accommodate, to the maximum extent possible, children of a range of developmental needs, mobility, and perceptual acuity is often described as universal design. ${ }^{22}$ Universal design focuses on creating a space to meet the needs of the highest number of people. A universally designed schoolyard consider inclusivity, accessibility for children at all developmental stages and abilities, offering a variety of activities for diverse users, appeal to the five senses, spaces easy to understand, being non-exhausting, create safe and appropriately sized spaces where children can explore, learn and play. In this context, a schoolyard based on universal design means:

- Schoolyards are the places where pupils, teachers, and families enter and use the facilities together. So, schoolyard from entrances to the activity areas must be accessible for everyone.

- All users can use the majority of features and spaces, instead of having separate "accessible features" for people with different limitations and arrangements must offer options for use of diverse users. Features like play equipment, planter boxes, fountains, or benches are of different heights and sizes to meet the needs of more people.

- Circulating and using the outdoor space must be simple, easy and intuitive enough to perceive for the pupils of all ages, all abilities and different cognitive levels using the schoolyard. Elements like colors, sounds, pictograms, textures or handrails etc. must be integrated into the design for easy perception and use.

- Smooth, even surfacing allows access to different activities with minimal effort. Materials, equipment, routes, surfaces, rest areas designed for the school-

\footnotetext{
${ }^{21}$ Kumar, 2008, pp. 455-486.

${ }^{22}$ New Jersey School Outdoor Area Working Group, 2007.
}

yard must be used by low effort and should not make it difficult to use.

- The design provides adequate space for all people to access and maneuver around play equipment and features, regardless of mobility.

- The outdoor space offers physical or learning opportunities to challenge all users, but minimizes hazards and provides the warning or fail-safe features. Handrails, surface material, curved edges are only some examples. Schoolyard surfaces should offer some stable paths paved with engineered wood, fiber, rubber mats or other material to access wheelchairs or visually impaired users' assistive devices.

\section{Method of the Study}

In the study, the physical space qualities of school gardens which will help the developmental processes including cognitive, physical, emotional, social, communicational development of pupils by contributing to the health, learning and motivation of the child, which will integrate school-nature-society relationship and how a schoolyard can be designed from a universal design perspective are discussed. Accordingly, the potential user needs including visually, auditory, physically impaired pupils, teachers, parents, and community members are involved in the design process. At the end of the study, through literature and acquired knowledge from physical analyses of the existing schoolyard, general design suggestions were made for

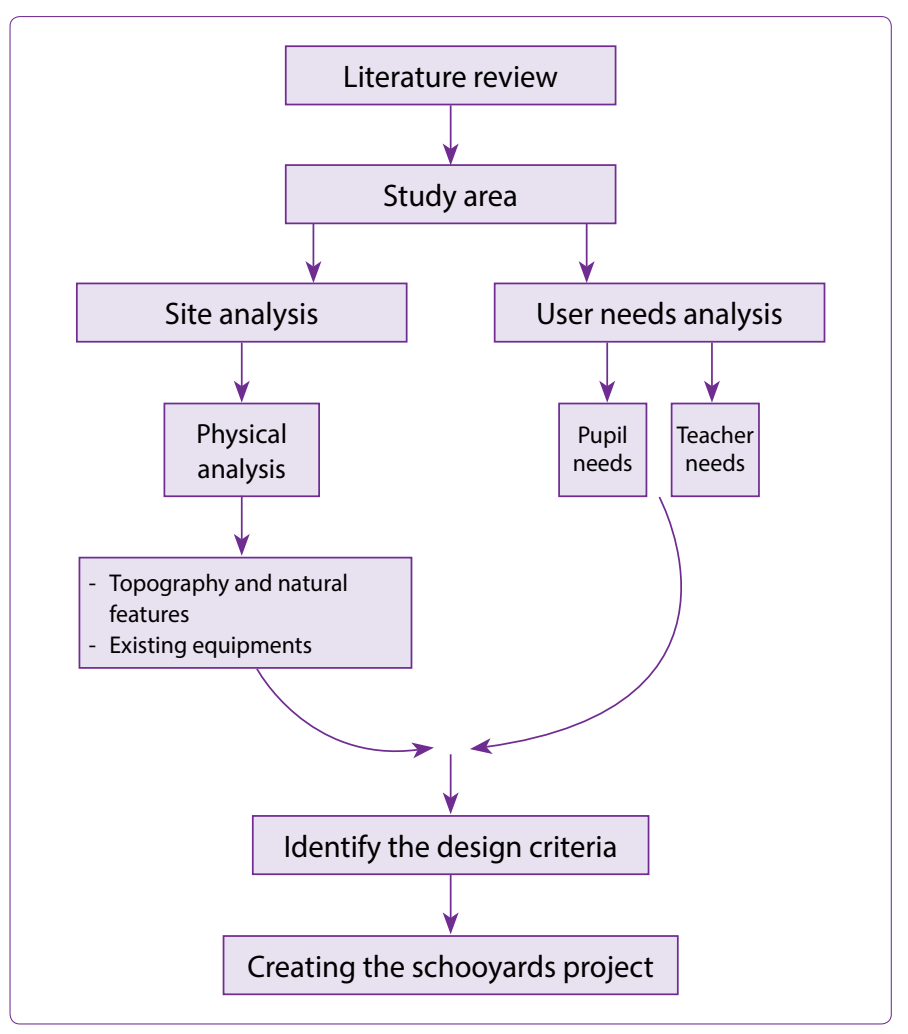

Figure 1. The basic framework of the study. 


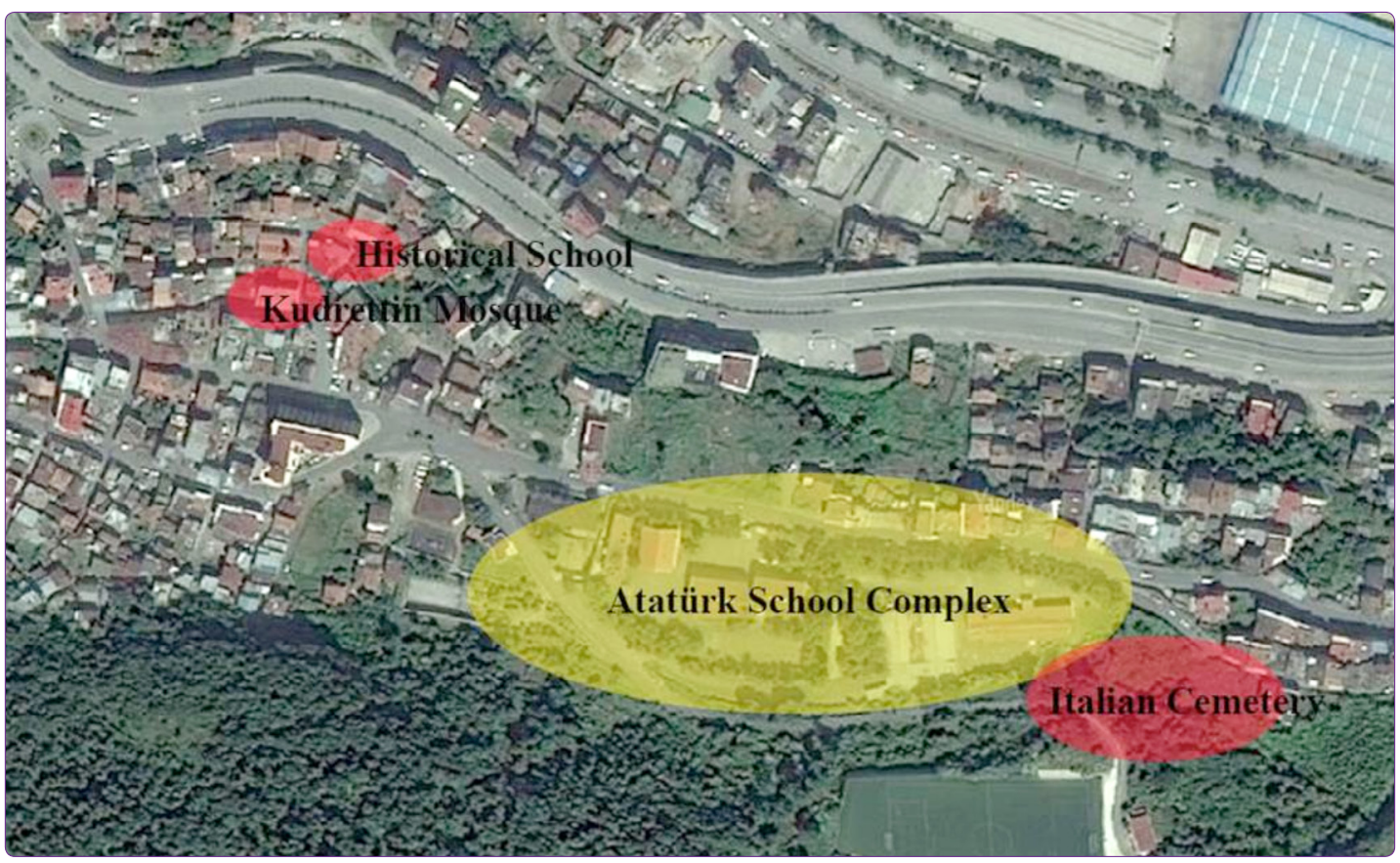

Figure 2. Aerial viewpoint of Atatürk school complex and its environment.
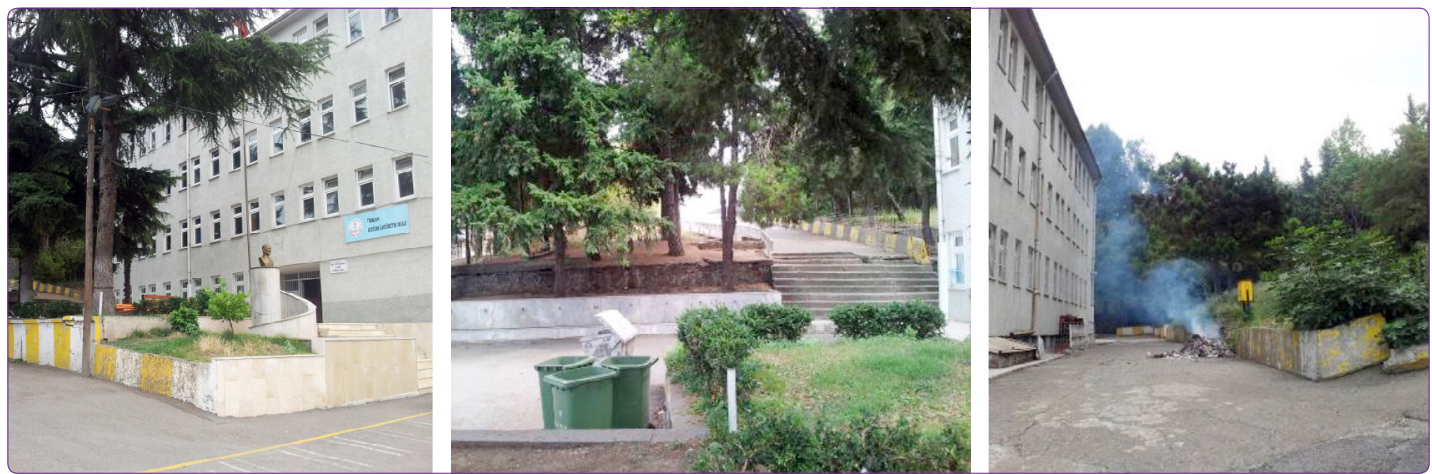

Figure 3. Views from Atatürk school complex and schoolyard.

schoolyard and a greener, more attractive, more secure, more accessible and more inclusive schoolyard project which will support pupils' learning, creativity, social interaction, make school open to community was produced.

The holistic version of different types of methods consisting of literature review, observation technique, interview technique and analysis of user drawings were used in the study. Pupils and teachers were encouraged to draw their requests/needs about the schoolyard. In this context, the basic framework of the study is presented schematically as below (Fig. 1).

\section{Study Area}

The study carried out in Atatürk School complex which is located near the city center of Trabzon in Turkey (Fig. 2). The reasons for choosing this school are: the school has the largest schoolyard in the city but neglected and functionless, the need of renewing the garden and the low socioeconomic and cultural structure of the neighborhood (so the family structure) in which the school is located (Fig. 3).

The total area of the schoolyard is $12500 \mathrm{~m}^{2}$ and in that scale, it is unique green area close to the city center, overlooking the sea and hosts lots of coniferous trees. In addition to the physical features of the school complex, the school is located in a historical environment. District in which school is located was used as a residential area first by the Iranians, and later by the Greeks. The region in the East of the school site is known as the Italian Cemetery. Kudrettin Mosque, which was built as a church in the $14^{\text {th }}$ century, is located on the Northwest of the school. The street, that takes its name from this mosque, carries feature of the residential area of fourteen consulates that belong to $19^{\text {th }}$ century. Also, the location has civil architecture examples such as registered and garden buildings and a historical school (Fig. 2). ${ }^{23}$

\footnotetext{
${ }^{23}$ Anonymous, 2013.
} 
Table 1. Physical analysis of schoolyard

\section{Physical elements Explanation}

Schoolyard The schoolyard which accommodates a kindergarten, a primary school, a secondary entrances school, and an atelier, has three entrances. The entrance located in the West is used for the entrances of teachers working at the school, guest and pupil service vehicles and pedestrians. The entrance located in the North accessed through stairs is used only by pedestrians. The third entry which is also located in the West was built later for service vehicles since automobile access cannot be provided for primary school through the other entrances due to the stairs in the area. In addition, in order to provide automobile access to the primary school building, a road was built through the green area between the secondary school and atelier buildings thereby dividing the green area into two pieces and causing it to lose its effectiveness.

Parking space

The north garden between the secondary school and kindergarten which is an important activity space due to its location serves as ceremony area and parking space for teacher-guest vehicles. The use of a part of the garden as parking space reduces and prevents pupils' from using garden space.

Garden wall

Ground covering

Green areas

Sport/play areas

Stair/ramps
Plant and grass surfaces which have quite a large area are neglected and unsuited for use. There is not any landscape arrangement for the green space. Therefore, these undersigned green areas are not safe for the pupils.

The wide garden space of the school provides a suitable area for sports/play areas; however, required and adequate arrangements cannot be observed at the sports/play areas. Additionally, although there are different age groups at the school, sports/play areas suited to age groups do not exist.
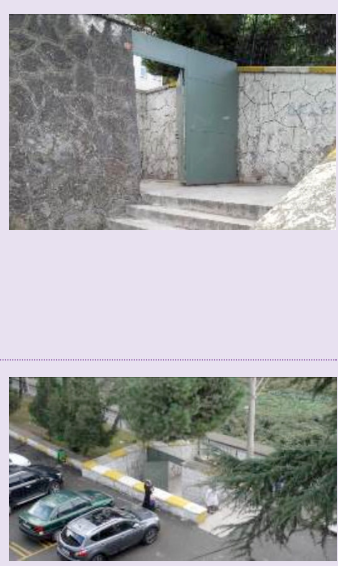

The garden of the school which has a type project (uniform projects designed for schools by the Turkish Ministry of Education) like other public schools in our country has been arranged in a haphazard fashion. Since type projects are usually developed for flat areas, the type projects which are applied to sloped areas have high supporting walls around the gardens. At the school where the study has been carried out, attention is drawn by the unappealing sight of high supportive walls built because of the slope on the Southern side of the school. Furthermore, the walls surrounding the school are in a poor condition with cracks, faded paint, damaged parts and vandalism here and there.
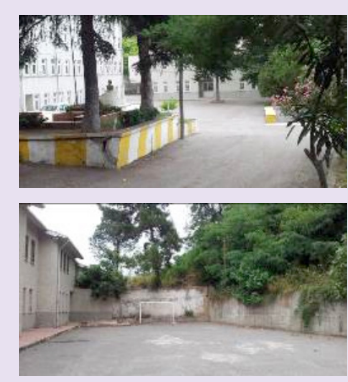

In the overall area of the school, concrete and asphalt surfaces have been used as ground covering. Both the hard surface covering material and the crack and collapses formed on the surface cause pupils to get injured.
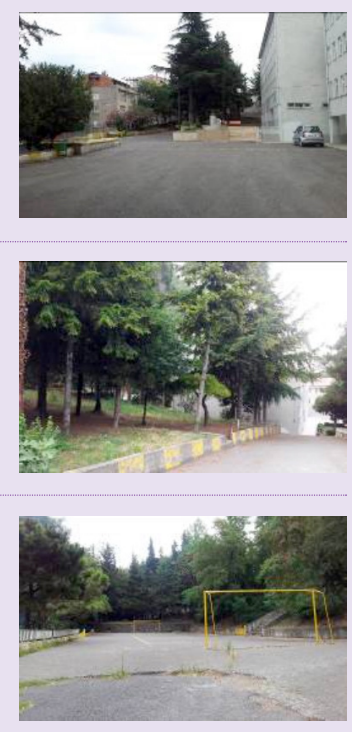

At the school which is built on a sloped area, passage/rise between different ground level is generally provided by stairs, the circulation of impaired/handicapped users is not taken into consideration, and ramps have not been included. Especially the fact that there is only stairway at the pedestrian entry prevents its usage by physically impaired pupils.

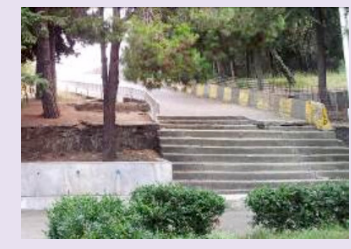


Table 1. Physical Analysis of Schoolyard (continuation)

$\begin{array}{ll}\begin{array}{l}\text { Physical elements } \\ \begin{array}{l}\text { Benches and } \\ \text { other outdoor }\end{array} \\ \text { furniture }\end{array} & \begin{array}{l}\text { Although the school is located in the city with a good view, has a wide and green area, } \\ \text { the number of outdoor furniture is quite few and they are neglected. The fountain at the } \\ \text { garden has broken taps and its maintenance is inadequate. Big garbage cans just behind } \\ \text { the Atatürk's Bust create an ugly sight. }\end{array} \\ \begin{array}{l}\text { The additions made to the atelier located behind the secondary school and primary } \\ \text { school buildings and its neglected look affects the aesthetics of the schoolyard in a neg- } \\ \text { ative way. }\end{array} & \begin{array}{l}\text { That there is no element of control at the school entrances creates a big security problem } \\ \text { throughout the school. Additionally, the unarranged and neglected garden of the school } \\ \text { causes reduction of user safety. }\end{array} \\ \text { Security } & \begin{array}{l}\text { The school garden isn't compatible with the principles of design for everybody and } \\ \text { doesn't provide the chance for impaired and non-impaired children to play together. } \\ \text { There isn't any arrangement for users having limitations (visual, mobility etc.) }\end{array} \\ \text { Arrangement for } \\ \text { universal design }\end{array}$

\section{Findings}

\section{Physical Analysis}

In the study, existing physical conditions and spatial characteristics of the schoolyard has been determined by observation technique and carrying out physical analysis on photos taken by the researcher, scaled layout plan acquired from the Municipality of Trabzon and aerial photographs. The data relating the physical analysis of the schoolyard has been examined under the following ten headings: school- yard entrances, parking space, garden wall, ground covering, green areas, sports/play areas, stairs/ramps, benches and other outdoor furniture, atelier, security and arrangement for universal design (Table 1, Fig. 4).

\section{User Need Analysis}

To provide the basic material of the study, $6^{\text {th }}$ and $8^{\text {th }}$ grade pupils were asked to explain their ideas for rearrangement of their schoolyard by using free techniques such as writing, drawing, painting etc. on layout plan of

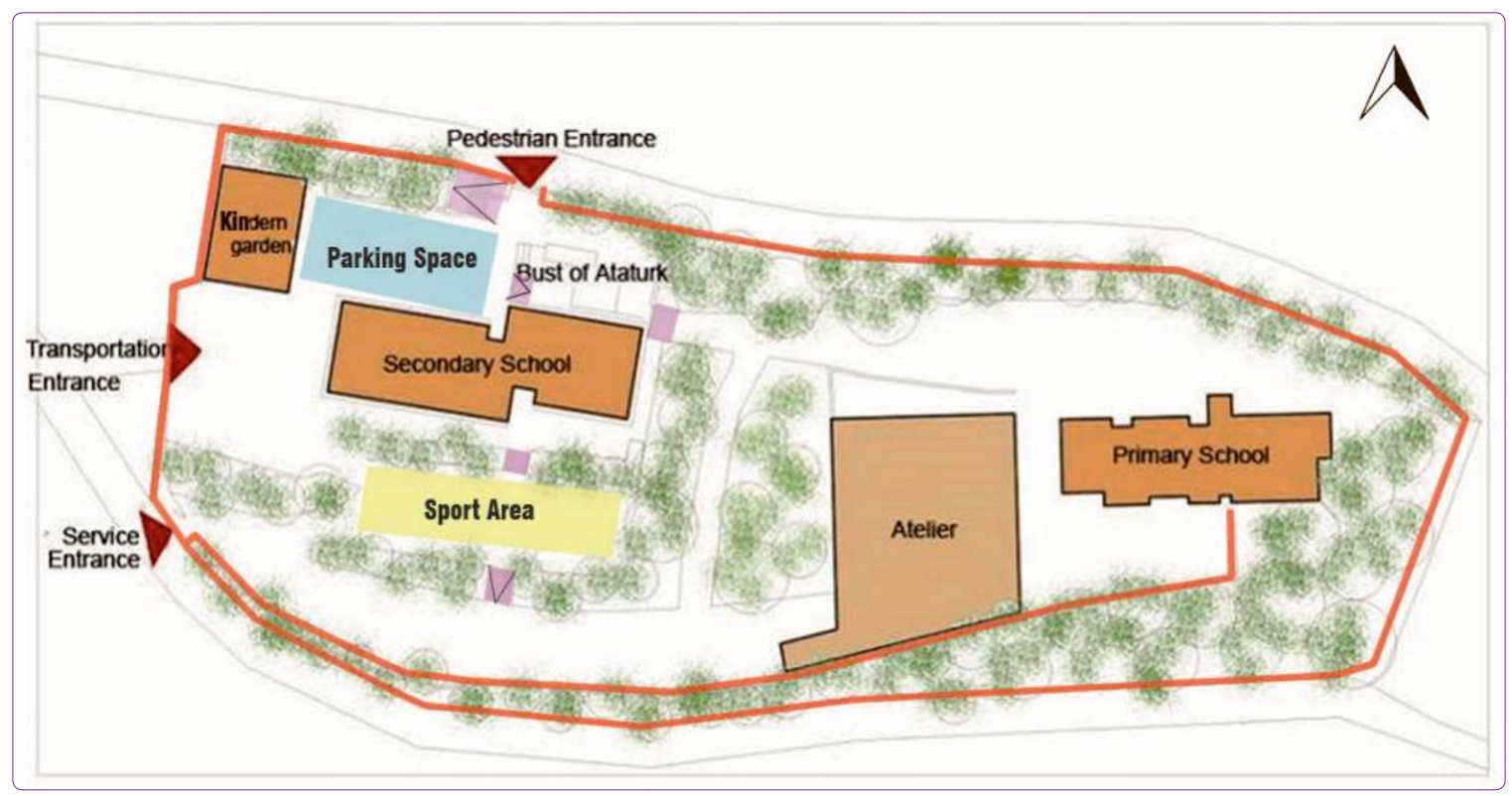

Figure 4. Existing schoolyard of Atatürk School Complex. 
school during the conducted workshop in visual arts course. The study which is performed with the pupils, conducted with teachers whose participation were voluntary. Furthermore, making oral interviews with the school director about recommendations for the development and renovation of the schoolyard has been evaluated.

18 pupils from $8^{\text {th }}$ grade (9 girls, 9 boys), 18 pupils from $6^{\text {th }}$ grade ( 6 girls, 12 boys) and 8 teachers giving education at the school ( 5 females, 3 males) participated in the study which was carried out in the Atatürk Kindergarten-Primary-Secondary School. The output containing the ideas of teachers and pupils about the rearrangement of their schoolyard has been analyzed separately.

\section{Pupil Needs Analysis}

Pupils' requests for the rearrangement of the school- yard are taking security precautions at the school entrance, sports/play areas, canteen-cafeteria, increasing the sitting areas, putting up nets on the football goal posts at the sports areas and making green areas better maintained. Other requested arrangements are; play areas suitable for young age groups, flower pots, football pitch (small size with fake grass), swimming pool, manmade pond, sandbox, toilets, fountain, bicycle park area, cafeteria, movie theatre, sports areas for female pupils, rubbish cans, automatic doors, running track, painting of garden walls, better lighting, better maintenance and cleaning of the fountain, changing of the parking space location. These arrangements which are requested and their locations on the layout plan of the school are shown in Figure 5. Most requested are indicated by large fonts and circles in the image. It was also found that pupils were quite uncomfortable with the smell at the

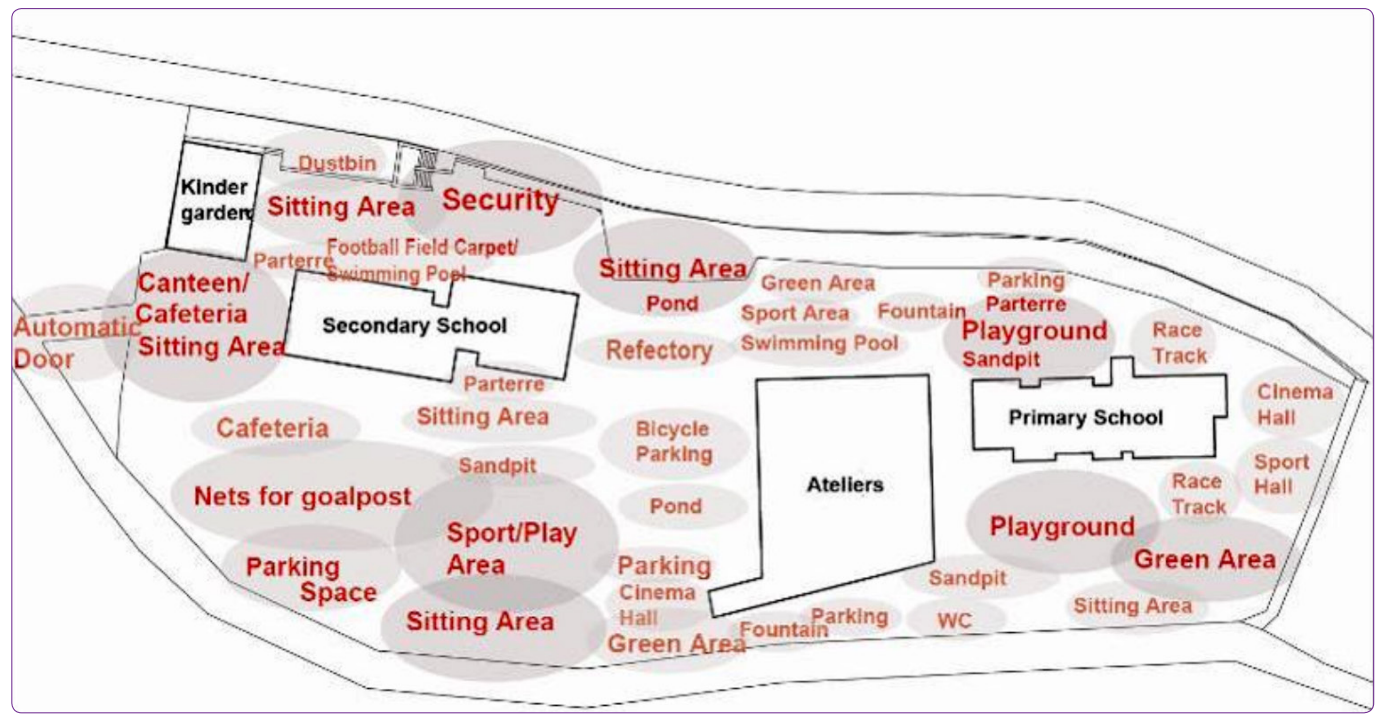

Figure 5. Needs of pupils about the rearrangement of their schoolyard.

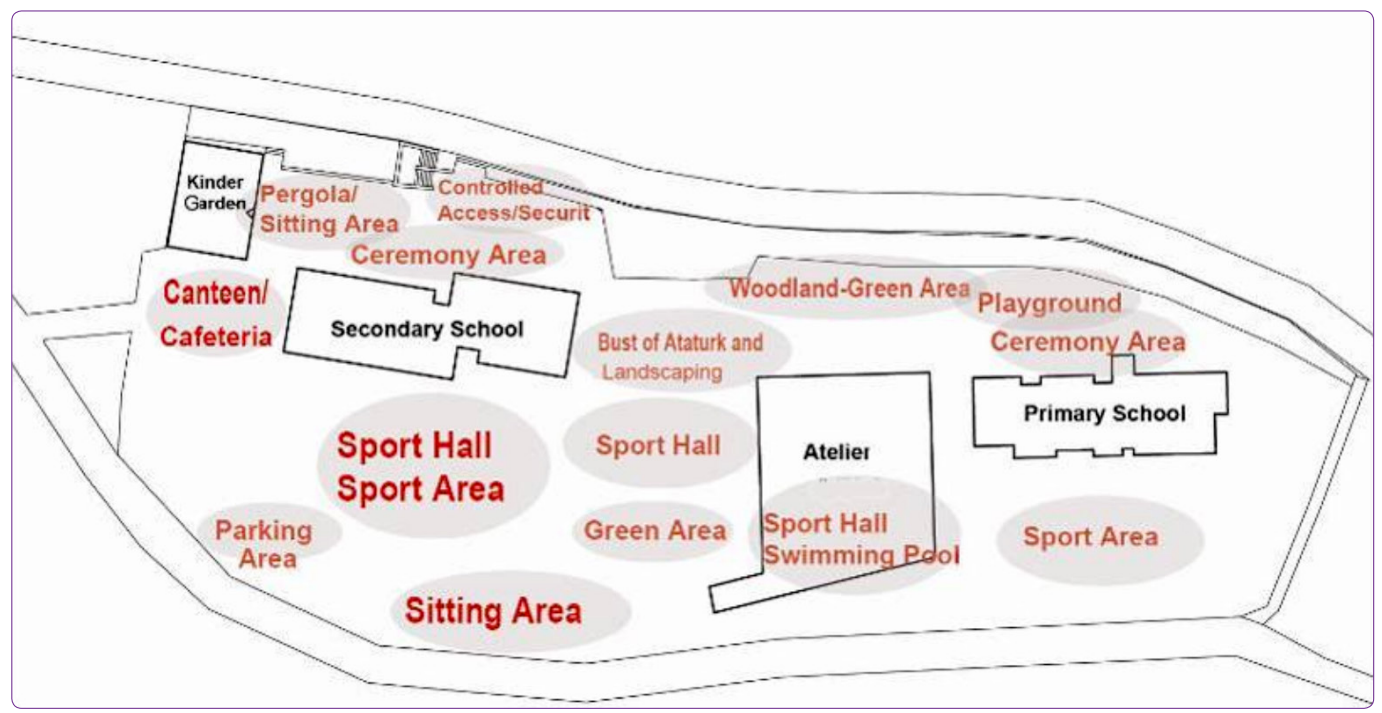

Figure 6. Needs of teachers about the rearrangement of their schoolyard. 
pedestrian entrance, car parking spaces, and the look of the atelier as well as the general security and maintenance problems throughout the school.

\section{Teacher Needs Analysis}

Teachers' requests for the rearrangement of the schoolyard are primarily the sports hall, canteen-cafeteria and increasing the sitting areas. The other arrangements requested to be made are; ceremony areas, green areas, play areas for young age groups, renewal of Atatürk's bust and its surrounding, the changing of the parking space, transforming atelier to sport hall, swimming pool, constructing of ramps instead of the stairs in the garden, changing the railings surrounding the school and precautions to be taken for security. These arrangements which are requested and their locations on the layout plan of the school are shown in Figure 6. Most requested are indicated by large fonts and circles in the image.

\section{Evaluation}

In the study, it was found that the school administration could not pay enough attention to the schoolyard due to limited budget and staff shortage. The security in the school garden was inadequate, therefore pupils could not spend time safely, comfortably and freely, the schoolyard was not suitable for using there out of school times and the arrangement of the schoolyard did not offer a convenient environment for different age groups, genders and physically disabled pupils (generally walking disabled and blind pupils). Especially female pupils were complaining about the garden arrangements because of not offering a variety of activities. The design elements existing at the schoolyard affected pupils' attitude, learning, playing and communication patterns with friends in a negative way.

\section{Evaluation of Field Work}

The current situation, needs of pupils, needs of teachers in terms of schoolyard entrances, parking space, ground cover, green areas, sports/game areas, stairs/ramps, benches, and other outdoor furniture, atelier, security and suggestions for these physical elements are shown in Table 2 as a summary of this study.

\section{Developing the Schoolyard Project}

After the analysis and evaluations, the next phase of the study is to design a schoolyard project. In the renovation of the existing schoolyard project, practicability and economic factors were taken in consideration beside the acquired knowledge from the needs of school users and

Table 2. Current situation, request of teachers, request of pupils about school's physical elements and suggestions for these elements

\begin{tabular}{|c|c|c|c|c|}
\hline Physical elements & Current situation & Request of teachers & Request of pupils & $\begin{array}{l}\text { Things to pay attention } \\
\text { in design process }\end{array}$ \\
\hline $\begin{array}{l}\text { Schoolyard } \\
\text { entrances }\end{array}$ & $\begin{array}{l}\text { There are three entrances } \\
\text { for pedestrians, vehicles } \\
\text { and serves entrances are } \\
\text { inadequate aspect of } \\
\text { physical condition. }\end{array}$ & & - Automatic doors. & $\begin{array}{l}\text { - Entrances should } \\
\text { be accessible for all } \\
\text { potential users. } \\
\text { - Entrances should reflect } \\
\text { the identity of school. }\end{array}$ \\
\hline Parking space & $\begin{array}{l}\text { Parking space reduces } \\
\text { and prevents pupils' from } \\
\text { using the garden. }\end{array}$ & $\begin{array}{l}\text { - Changing of the parking } \\
\text { space location. }\end{array}$ & $\begin{array}{l}\text { - Bicycle park area } \\
\text { - Changing of the parking } \\
\text { space location. }\end{array}$ & $\begin{array}{l}\text { - It should be far from } \\
\text { classrooms. } \\
\text { - It should not obstruct } \\
\text { the use of play, sports } \\
\text { and ceremony areas. } \\
\text { - It should be isolated from } \\
\text { the rest of the garden } \\
\text { with a green band. }\end{array}$ \\
\hline Garden wall & $\begin{array}{l}\text { The walls surrounding } \\
\text { the school are in a poor } \\
\text { condition with cracks, } \\
\text { faded paint, damaged } \\
\text { parts and vandalism. } \\
\text { - The supporting wall on } \\
\text { the southern side is quite } \\
\text { high. }\end{array}$ & $\begin{array}{l}\text { - Changing of the railings } \\
\text { surrounding the school. }\end{array}$ & - Painting of garden walls. & $\begin{array}{l}\text { - They should be repaired } \\
\text { and painted. } \\
\text { - Some part of garden wall } \\
\text { can be painted by pupils. } \\
\text { - They should not be too } \\
\text { high that it separate } \\
\text { school from district. }\end{array}$ \\
\hline
\end{tabular}


Table 2. Current situation, request of teachers, request of pupils about school's physical elements and suggestions for these elements (continuation)

\begin{tabular}{|c|c|c|c|c|}
\hline Physical elements & Current situation & Request of teachers & Request of pupils & $\begin{array}{l}\text { Things to pay attention } \\
\text { in design process }\end{array}$ \\
\hline Ground covering & $\begin{array}{l}\text { - Concrete and asphalt } \\
\text { surfaces have been used } \\
\text { as ground covering. } \\
\text { - Covering material, crack } \\
\text { and collapses formed on } \\
\text { the surface cause pupils } \\
\text { to get injured. }\end{array}$ & & & $\begin{array}{l}\text { - Instead of uniform } \\
\text { use of asphalt and } \\
\text { concrete surfaces, natural } \\
\text { materials such as sand, } \\
\text { tree bark, wood etc... } \\
\text { should be used at the } \\
\text { suitable places for the } \\
\text { security use of all pupils. }\end{array}$ \\
\hline Green areas & $\begin{array}{l}\text { Plant and grass surfaces } \\
\text { are neglected and } \\
\text { unsuited for use. } \\
\text { - They are not safe for the } \\
\text { pupils. }\end{array}$ & $\begin{array}{l}\text { - Maintenance of green } \\
\text { areas }\end{array}$ & $\begin{array}{l}\text { Making green areas } \\
\text { better maintained. }\end{array}$ & $\begin{array}{l}\text { - Existing green areas } \\
\text { should be protected. } \\
\text { - They should be made } \\
\text { suitable for use by } \\
\text { maintaining and } \\
\text { arranging. } \\
\text { - Building plant growing } \\
\text { gardens. }\end{array}$ \\
\hline Sport/play areas & $\begin{array}{l}\text { - There are not required } \\
\text { and adequate } \\
\text { arrangements in the } \\
\text { sport/play areas. } \\
\text { - These areas are not } \\
\text { suited for the different } \\
\text { age groups and for users } \\
\text { having limitations. }\end{array}$ & $\begin{array}{l}\text { - A sport hall. } \\
\text { - A swimming pool } \\
\text { - Play areas for young age } \\
\text { groups. }\end{array}$ & $\begin{array}{l}\text { - More sports/play areas. } \\
\text { - Putting up nets on the } \\
\text { football goal posts at the } \\
\text { sports areas. } \\
\text { - Play areas suitable for } \\
\text { young age groups. } \\
\text { - Football pitch. } \\
\text { - Swimming pool. } \\
\text { - Manmade pond } \\
\text { Sandbox. } \\
\text { - Sports areas for female } \\
\text { pupils. } \\
\text { - Running track. }\end{array}$ & $\begin{array}{l}\text { - They should present a } \\
\text { variety of environments } \\
\text { for age and gender } \\
\text { groups. } \\
\text { - Design of play areas } \\
\text { should not be finished } \\
\text { completely, it should has } \\
\text { unfinished parts that let } \\
\text { the user organize and } \\
\text { re-design some parts. } \\
\text { - Sport areas suitable for } \\
\text { wheelchair uses. }\end{array}$ \\
\hline Stair/ramps & $\begin{array}{l}\text { - Passage between } \\
\text { different ground level is } \\
\text { generally provided by } \\
\text { stairs. } \\
\text { - The circulation of } \\
\text { mobility impaired } \\
\text { users is not taken into } \\
\text { consideration } \\
\text { - Ramps have not been } \\
\text { included. }\end{array}$ & $\begin{array}{l}\text { - Constructing of ramps } \\
\text { instead of the stairs in } \\
\text { the garden. }\end{array}$ & & $\begin{array}{l}\text { - Circulation of the } \\
\text { schoolyard should be } \\
\text { compatible with the } \\
\text { principles of design for } \\
\text { everybody. } \\
\text { - Circulation should } \\
\text { provide chance } \\
\text { for impaired and } \\
\text { non-impaired children. }\end{array}$ \\
\hline
\end{tabular}

literature. The main fiction of the project is the preservation of green area and creating an open-air space which can be used by all people (Figs. 7, 8 and 9). In this context, applications in the re-design of schoolyard project can be summarized as below.

- Multi-purpose use of schoolyard (ceremony areas, 
Table 2. Current situation, request of teachers, request of pupils about school's physical elements and suggestions for these elements (continuation)

\begin{tabular}{|c|c|c|c|c|}
\hline Physical elements & Current situation & Request of teachers & Request of pupils & $\begin{array}{l}\text { Things to pay attention } \\
\text { in design process }\end{array}$ \\
\hline $\begin{array}{l}\text { Benches and other } \\
\text { outdoor furniture }\end{array}$ & $\begin{array}{l}\text { - The number of outdoor } \\
\text { furniture is quite few and } \\
\text { they are neglected. }\end{array}$ & $\begin{array}{l}\text { - Increasing the sitting } \\
\text { areas. } \\
\text { - Renewal of Atatürk's bust } \\
\text { and its surrounding. }\end{array}$ & $\begin{array}{l}\text { - Increasing the sitting } \\
\text { areas. } \\
\text { - Flower pots. } \\
\text { - Fountain. } \\
\text { - Rubbish cans. } \\
\text { - Better lighting. } \\
\text { - Better maintenance and } \\
\text { cleaning of the fountain. }\end{array}$ & $\begin{array}{l}\text { - Number of sitting } \\
\text { elements and their } \\
\text { material quality should } \\
\text { be increased. } \\
\text { - Fountain should be } \\
\text { renewed with different } \\
\text { heights. } \\
\text { - Place of rubbish cans } \\
\text { and their model should } \\
\text { be changed. } \\
\text { - There should be space } \\
\text { next to benches for } \\
\text { wheelchair. } \\
\text { - Design of Atatürk's bust } \\
\text { should be changed and } \\
\text { surrounding platform of } \\
\text { bust should be enlarged. } \\
\text { - Play equipment should } \\
\text { be placed in the play } \\
\text { area according to user } \\
\text { age. } \\
\text { - Art walls should be } \\
\text { designed for pupils with } \\
\text { different capabilities. }\end{array}$ \\
\hline Atelier & $\begin{array}{l}\text { The additions made } \\
\text { to the atelier and its } \\
\text { neglected look affects } \\
\text { the aesthetics of the } \\
\text { schoolyard in a negative } \\
\text { way. }\end{array}$ & $\begin{array}{l}\text { - Transforming atelier to } \\
\text { sport hall. }\end{array}$ & & $\begin{array}{l}\text { - Atelier should be pulled } \\
\text { down and place of it } \\
\text { should be used as open } \\
\text { air classroom or it can } \\
\text { be transformed into } \\
\text { multifunction hall or } \\
\text { sport hall giving different } \\
\text { usage opportunity to all. }\end{array}$ \\
\hline Security & $\begin{array}{l}\text { - The lack of security } \\
\text { control in the entrance of } \\
\text { school, the unarranged } \\
\text { and neglected garden } \\
\text { causes safety problem. }\end{array}$ & $\begin{array}{l}\text { - Taking precautions for } \\
\text { security. }\end{array}$ & $\begin{array}{l}\text { - Taking security } \\
\text { precautions at the school } \\
\text { entrances. }\end{array}$ & $\begin{array}{l}\text { - Security cabin should } \\
\text { be built near the school } \\
\text { entrances. } \\
\text { - Handrail, railings and } \\
\text { curved edges should be } \\
\text { used for safe usage for all } \\
\text { users. }\end{array}$ \\
\hline
\end{tabular}

plant growing garden, play areas, art walls, picnic areas, car parking, sand pool, sitting areas...etc.) was provided (Fig. 10),

- Spaces which helps different age and gender groups and pupils having different limitations to be social- ized with together were designed,

- Existing green areas were preserved, and natural elements as hills were designed in the green areas (Fig. 10),

- Plant growing gardens which contribute science 


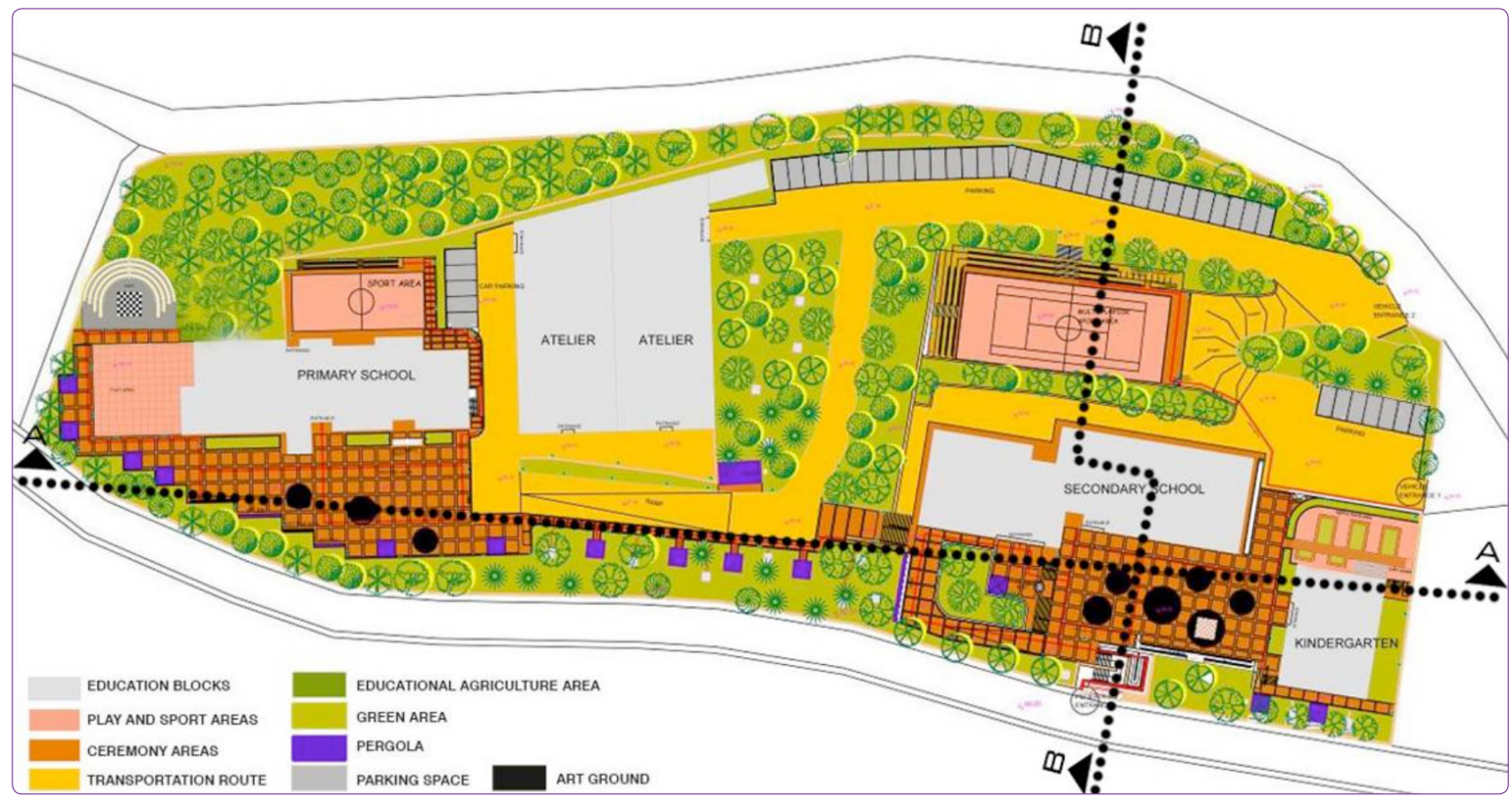

Figure 7. New schoolyard project's site plan.

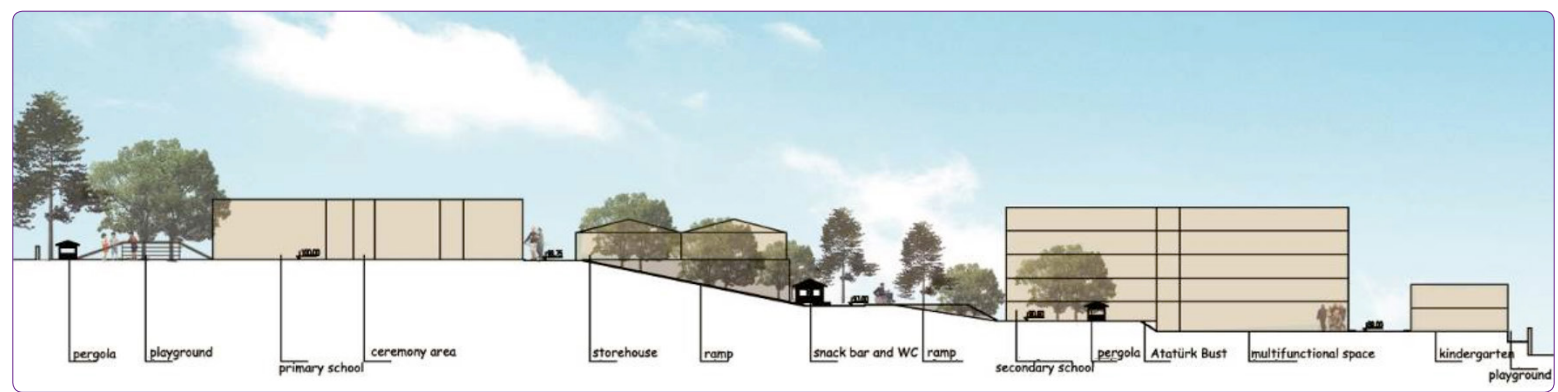

Figure 8. New schoolyard project's section A-A.

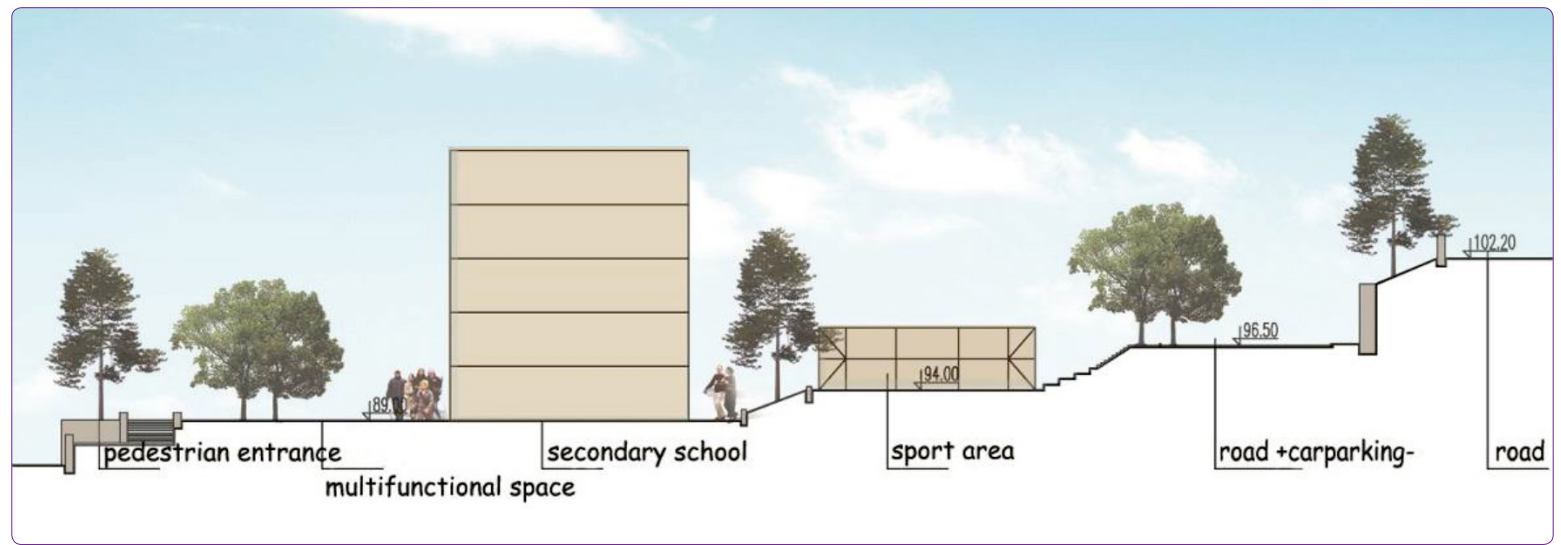

Figure 9. New schoolyard project's section B-B.

lessons, experiential learning and nature awareness were designed in the north-west of the schoolyard near the kindergarten school building (Fig. 11).

- Rubber and natural stone for ground covering and wooden materials for the sitting elements were used,

- The surrounding platform of Atatürk's bust was en- larged (Fig. 10),

- A new fountain with different heightened-faucets was designed in the place of old foundation (Fig. 10),

- Play equipment was placed in the play area near the kindergarten and primary school buildings according to user age, for the use of children with different ca- 


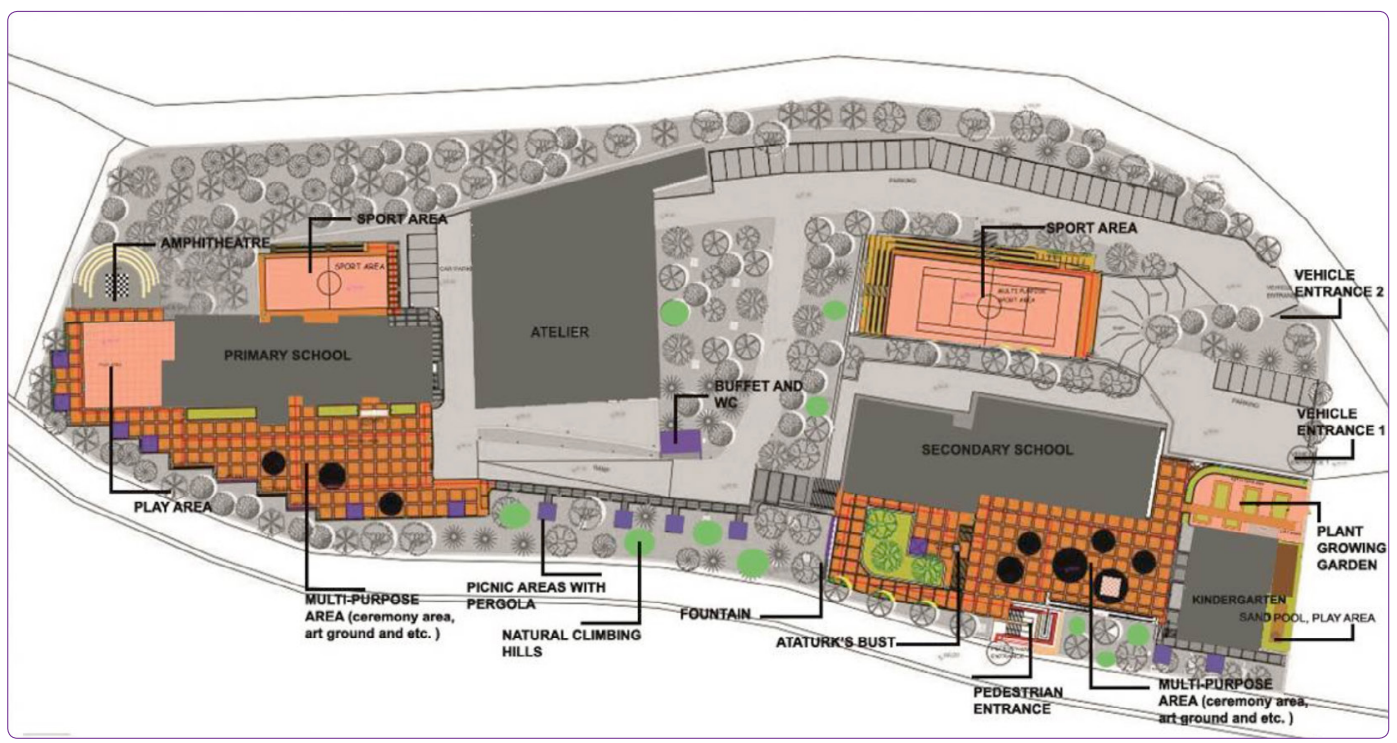

Figure 10. Rearrangements in new schoolyard project.

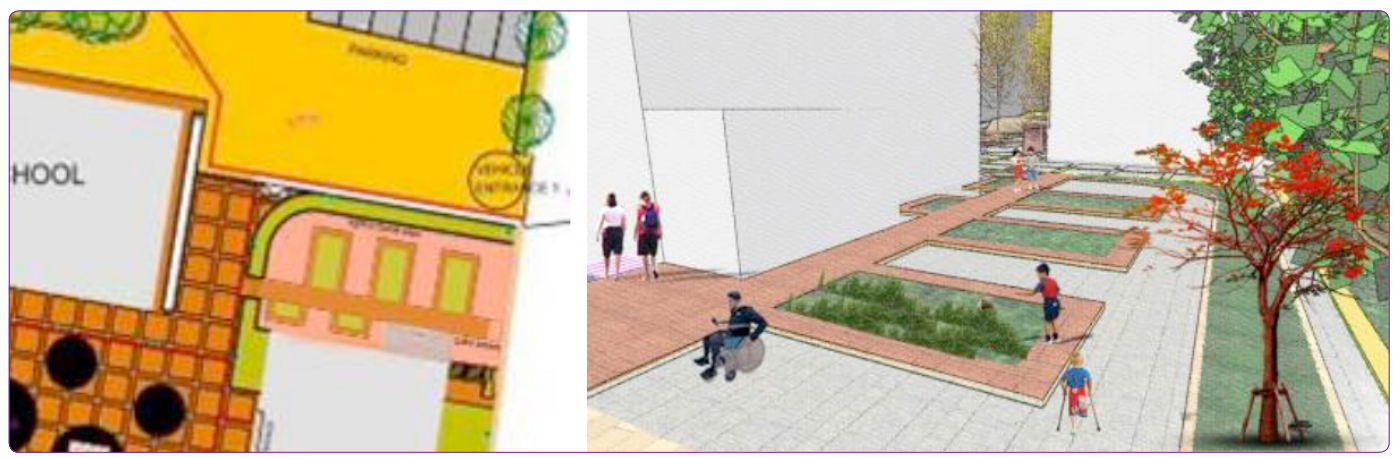

Figure 11. Plan and image of plant growing gardens near the kindergarten school building.

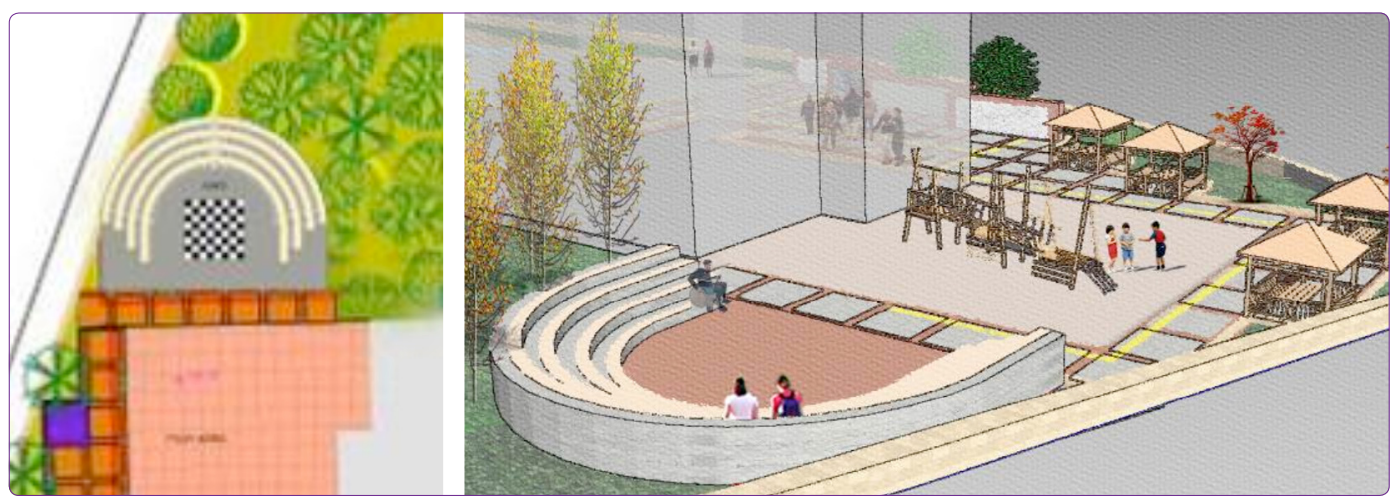

Figure 12. Plan and image of play area and open air amphitheater near the primary school.

pabilities, and also an open-air amphitheater which has a sitting/waiting area for wheelchair users were designed near the primary school (Fig. 12),

- Art walls and grounds which has suitable usage for people in different ages, gender, limitations and provide pupils with opportunity for feeling themselves belong to their schools and improving their creativity were designed in the ceremony areas of primary and secondary schools (Figs. 13 and 14).

- Car parking areas were moved away from classrooms (in front of the south retaining walls and near the vehicle entrance), play and ceremony areas and isolated rest of the garden with a green band (Fig. 10),

- For providing to make school open to society, picnic tables which were turned towards to scenery, buffet, and WC were placed on suitable places in the north 

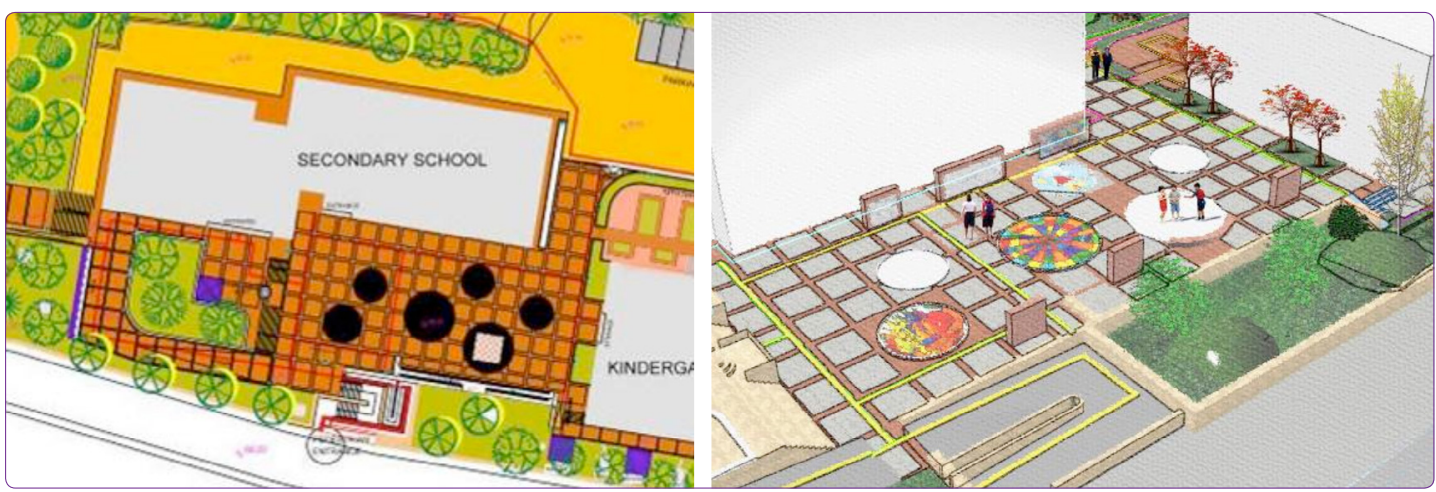

Figure 13. Plan and image of art walls and grounds in the ceremony areas of secondary schools.
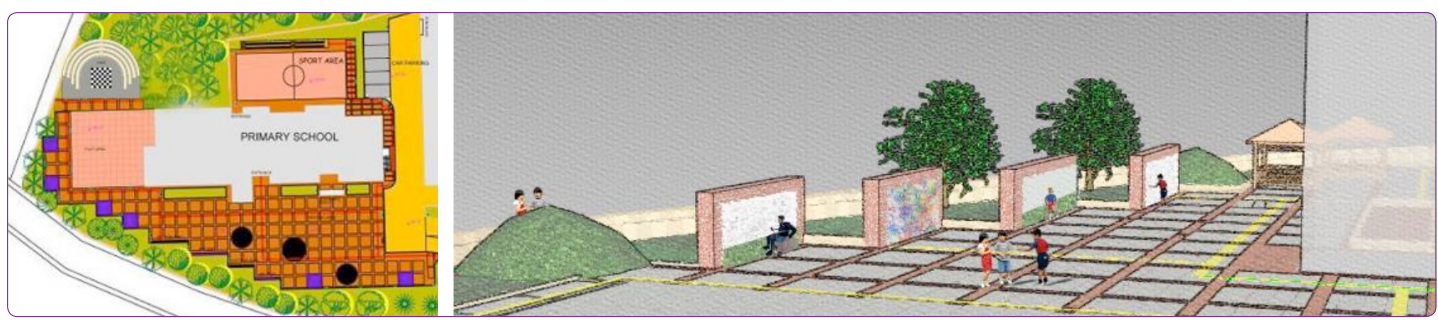

Figure 14. Plan and image of art walls and grounds in the ceremony areas of primary schools.

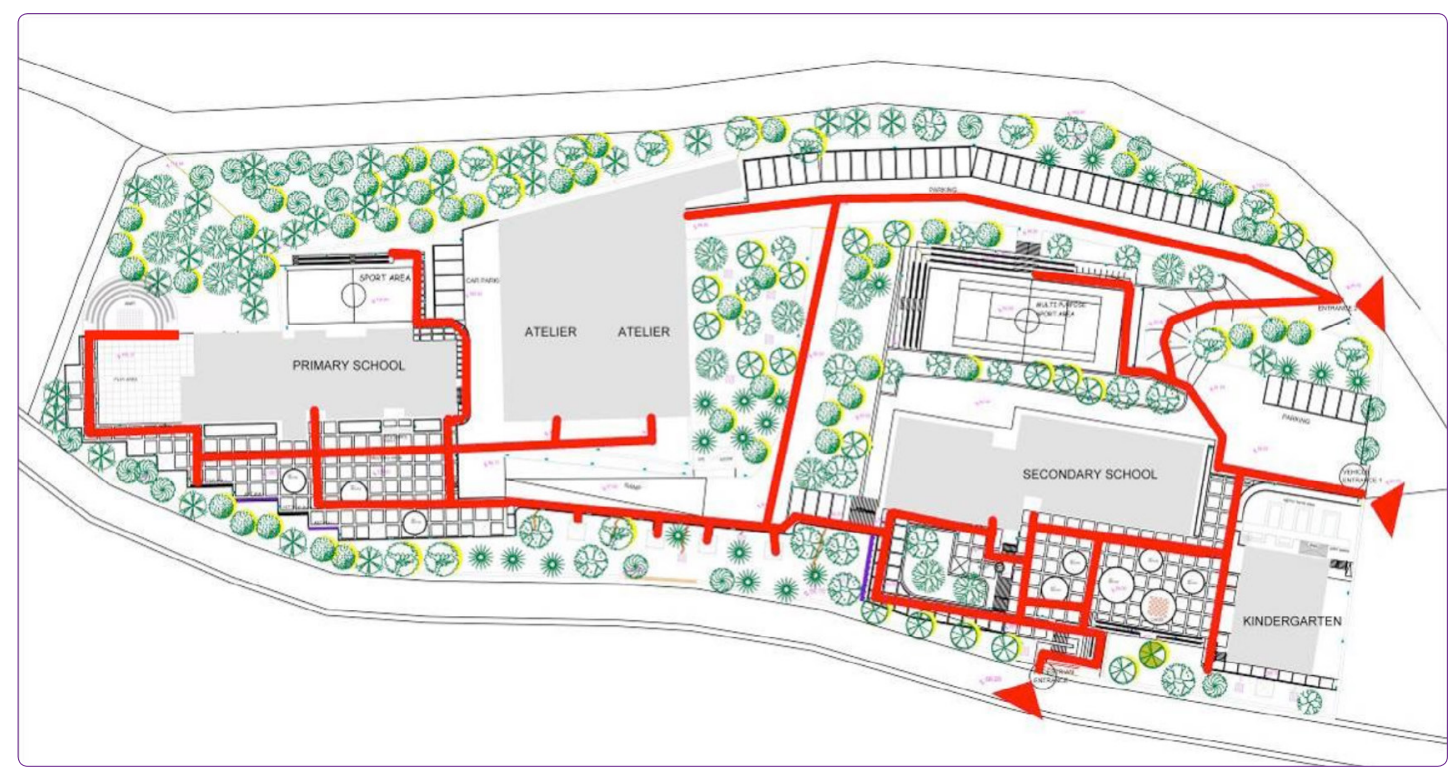

Figure 15. Circulation route for all users.

of the schoolyard for inhabitants of the district to use school ground after school hours (Fig. 10),

- In the content of the project, existing buildings of atelier were planned to be transformed into openair classrooms or sports areas, but these buildings conserved as were because the local administration didn't let for changing the function of these buildings (Fig. 10),

- In the schoolyard, access controlled entrances were provided.
- In the schoolyard there are so many different levels, thus to provide accessing between different levels, ramps were designed alternatively to stairs, and also different texture materials were used on the surface of the ground for generating circulation routes for users with visual impairments. School entrances were rearranged by taking in consideration of users with walking disabled. In this context, in the North pedestrian accessed of the schoolyard addition to stair, a ramp was designed. Also, on the surrounding tribune of sports areas, special places for sitting 
Table 3. The improvements, schematic expression of these improvements and general outcomes about schoolyard

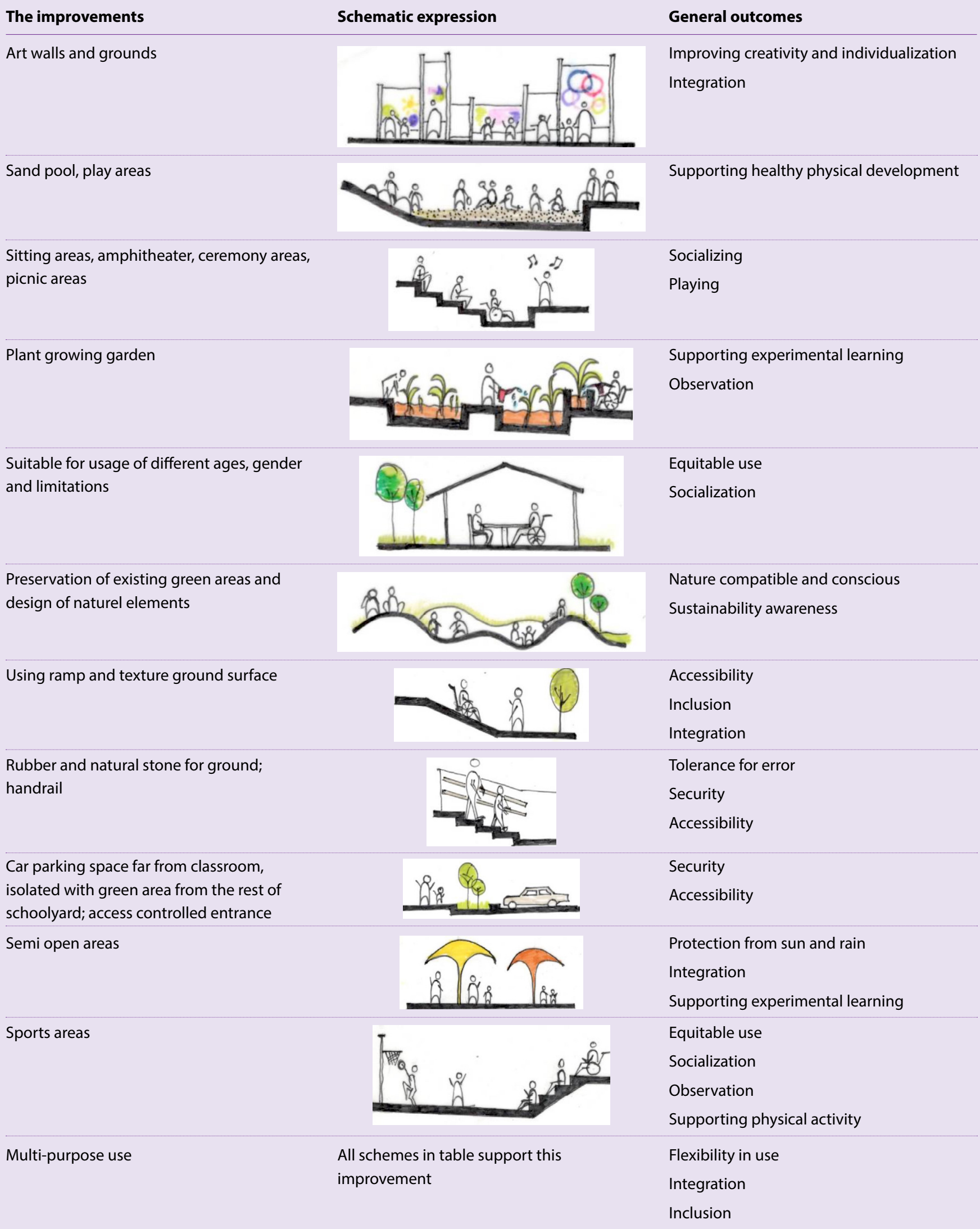


of the walking disabled users were designed. When looking at the circulation route it is evident that every part of the school is suitable for the pupils with different limitations (mobility, blind or confused etc.) by using ramp and texture ground surface. With these arrangements, schoolyards can be used equally by all potential users (Fig. 15).

\section{Results}

Because of the lack of open outdoor spaces for children in our crowded and unplanned environments, school grounds are the most effective developmental outdoor spaces for children in playing, teaching, learning and socializing activities. In this context, the scopes of the study are to emphasize that the school garden, where pupils, teachers, and parents of different age, gender, capacity, and limitations use, has an essential role in learning and socialization, to define the importance of universal design in schoolyards and to explain the process and the improvements of redesign of the existing schoolyard with an inclusive approach.

The current situation of the school garden, which has a large surface and green area, is quite neglected. The green areas didn't take a role in school life except for the visuality. The lack of alternative solutions about level changes in the area reduces accessibility both on the entrances and in the garden. Therefore, pupils or teachers in limited mobility (temporary or permanent) couldn't use the garden easily and entirely. The arrangement of garden is not suitable for the use of pupils in different age groups and capacities and the schoolyard doesn't offer an opportunity for activities which support sports, learning, and socialization for all. High garden walls that break school's connection with surroundings, parking areas dividing green areas and schoolyard, lack of benches, fountains, outdoor equipment, and playing furniture etc., security problems in the entrance and all around in the schoolyard and are the deficiencies of the schoolyard. So, it can be said that the inclusive and integrating character of universal design wasn't taken into consideration.

Considering current design problems and universal design criteria in mind, a schoolyard design was developed to make the schoolyard suitable for the potential users in maximum extend including different age, gender, capacity or limitation. Sports areas, tribunes and an open amphitheater are designed near the school buildings including spaces for wheelchair users. Playing areas and equipment for primary school and kindergarten are installed, pergolas with tables and benches, buffet and WC, seating areas, and fountain with various heights for easy use considering users with wheelchair or crutches are placed at the north. Multi-purpose spaces as ceremony areas are designed enabling various activities (art, paint, exhibition etc.), an accessible route with ramps tie ceremony areas and integrate the pupils in different ages, genders, and various limitations. Plant growing areas, climbing hills, and sandpits are added for effective learning and playing.

Improving the quality of the physical space isn't only important for child's active development, it also enhances the visual and functional image of the school environment. Thus it will positively affect the environment and the school can be opened to use of neighborhood. In the redesign of the schoolyard, there are some improvements made to create schoolyard suitable for everyone which contributes to the physical, cognitive, mental, emotional development of the pupils and which integrate the users of the school and school with the society. In this context, the improvements, schematic expressions, and general outcomes were summarized in Table 3.

Feelings belong to space or building increase users' comfort, this also affects users' life quality and working performance in a positive way. Thus, user involvement in the design process is quite important issue. ${ }^{24}$ In this context, when looking at the educational buildings, pupils and teachers should have right to speak in the process of school and its environment's design, planning, renewing and furnishing for an active learning environment. Pupil and teacher involvement into the design has positive effects on performance, belonging to school, responsibility, and decreasing vandalism.

As a result, designers have a great responsibility for the design of the school gardens in which pupils who are in an important period of their development and spend most of their free time in. The school gardens of the 21st century should support academic, social and recreational activities, reflect the culture of both the school and the society they belong to and should help the integration of the school and the society with the help of universal design thinking.

\section{References}

Abend, A. C. (2001) Planning and Designing for Pupils with Disabilities, Washington D.C: National Clearinghouse for Educational Facilities.

Anonymous, (2013) 2011-2012 Education Term Briefing File of Atatürk Primary-Secondary School.

Arbogast, K. L., Brian CP K., Jeffrey L. K. and Bradley R. He. (2009) "Vegetation and Outdoor Recess Time at Elementary Schools: What are the Connections?" Journal of Environmental Psychology, vol. 29, no. 4, pp.450-456.

Education Development Center. (2000) Schoolyard Learning: The Impact of School Grounds, Massachusetts: Newton.

Johnson, D. (1998) "Many Schools Putting an End to Child's Play" The New York Times, No. 7.

\footnotetext{
${ }^{24}$ Walden, 2009.
} 
Johnson, J, M. (2007) Design for Learning: Values, Qualities and Processes of Enriching School Landscapes, Washington, DC, American Society of Landscape Architects.

Johnson, J., Christie, J. and Wardle, F. (2010) The Importance of Outdoor Play for Children, Retrieved from: http://www.communityplaythings.com/resources/articles/2010/outdoor- play.

Kumar, R., O’Malley, P. M. and Johnston L. D. (2008) “Association Between Physical Environment of Secondary Schools and Student Pupil Problem Behavior" Environment and Behavior, vol. 40, no.4, pp. 455-486.

Lynch, K. (1995) City Sense and City Design: Writings and Projects of Kevin Lynch, MIT Press.

Menino, T. M. (2000) Designing Schoolyards \& Building Community, USA The Boston Schoolyard Initiative.

Nabhan, G. P. and Stephen, T. (1995) The Geography of Childhood: Why Children Need Natural Places, Boston, MA: Beacon Press.

New Jersey School Outdoor Area Working Group. (2007) Schoolyard Planning and Design in New Jersey, Enhancing Outdoor Play and Learning, Newark, NJ: The Center for Architecture and Building Science Research New Jersey Institute of Technology.

Sanoff, H. (2009) "School Designed with Community Participation" Ed.: Rotraut Walden (editor) Schools for the Future, Germany: Hogrefe\&Huber Publishers.

Stoneham, J. (1997) "Health benefit" Landscape design: Journal of Landscape Institute, vol. 249, pp. 23-26.

Titman, W. (1994) Special Places; Special People: The Hidden Curriculum of School Grounds., Green Brick Road, 429 Danforth Ave., Ste.\# 408, Toronto, Ontario, Canada M4K 1 P1.

OWP/P Cannon Design, VS Furniture and Bruce Mau Design. (2010) The Third Teacher, New York: Abrams Book.

Özdemir, A. and Mehmet Corakci. (2010) "Participation in the Greening of Schoolyards in the Ankara Public School System" Scientific Research and Essays, Vol. 5, no. 15 pp. 2065-2077.

URL-1 www.rickhanson.com (Accessed 24 October 2017).

Walden, R. (2009) Schools for the Future, Germany: Hogrefe\&Huber Publishers.

Warren, D. H. (1994) Blindness in Children: An Individual Differences Approach, New York: Cambridge University Press. 